\title{
ローマ壁画における静物画を連ねた構成について Serial Disposition of Still Life Motifs in the Roman Wall-Painting
}

\author{
飯 島 章 仁 \\ IIJIMA Akihito
}

\begin{abstract}
In the Pompeian wall-painting, we can see depictions of wild birds, animals, fruits, fishes, bottles, plates etc. These themes are seemingly very similar to the still life motif of our age. But they may have connotation different to ours. In ancient Greece, dining and symposion were held as part of some religious rite. This ceremonial nature is discernible also in the Pompeian wall-painting, where depictions of hanged birds or dedicated fruits are sometimes visible by the side of altars. We can interpret these representations as reminiscent of old tradition of ceremonial dining.

In the Pompeian wall-painting, panel-like flamins were used to array representations of various kind of these themes. Sometimes they are composed to make serial arrangement of still life motifs, located in the series of panel-like pictures of middle zone or in the frize-like area of upper zone of wall.

Serial disposition of still life is often found in the rooms of symposion or dining called as triclinium or oecus. These motifs may be used to demonstrate the variety of different agricultural products or wild creatures of estate of host family. Representation of variety and richness of domestic products is very suitable each to show the generosity and hospitality of hosts, as well as the aesthetic value of their skillful depiction.
\end{abstract}

\section{はじめに}

古代ギリシャの饗宴は，祭祀的性格を強く残していた。コリントやアテネなどでは, 市民の代表が行なう国家祭祀としての集団食事と饗宴の施設が発掘されている。そこで は神々への感謝の奉献に続き，伝統に従った簡素な食事が行なわれた。

こうしたことを反映してか，ポンペイ遺跡でもとりわけ饗応のための部屋（トリクリ ニウム，オエクス）の壁画には, 神祠への奉納物の描写が散見される。「ラビリントの家」

（VI 8-10）のオエクス43の第二様式の壁画（図 1) では, 側壁の中央に神祠らしい円堂 の描写があり，その手前に四肢を縛られた猪が奉納され，これを挾む仕切壁には羽毛を

* 岡山市立オリエント美術館学芸員

Curator, Okayama Orient Museum 
剝がれた鳥が紐で吊り下げられている。こんにちの絵画ジャンルでいう「静物画」の主 題にも時代によって独特の意味が込められていることを，この事例は証している。

しかし，ポンぺイ壁画にはこうした伝統的な傾向が残存する一方で，これとは別に， 一室の壁面にいくつもの静物画を描き連ねて多様なヴァラエティを示すことも行なわれ ている。本稿ではそうしたものの事例を集めて，このことの意味や室内装飾の歴史に占 める位置を考えることにしたい。

\section{I． 食事や饗宴の部屋の例}

現代のそれと意味内容が相違する可能性を前提としつつも，ポンペイなどの古代ロー マ壁画に描かれた家禽や野鳥, 小四足獣, 魚介類, 野菜, 果物, 茸, パン, 食器類, 容 器類などのさまざまな人像表現によらない主題を，便宜上「静物画」の名で呼ぶことす (3) る。

壁面にこの主題が連続的に表わされた最初例は, 第二様式後期 (IIa) のポンペイの「ク リプトポルティコの家」(I 6,2) のオエクス22である(図 2 ）。両側壁に出入口がある奥 行きの浅い前室部に，食事や饗宴の場となった主室部が続いている。ここでは壁面のオ ルトスタットの部分を男女のヘルマ柱のカリアティドが区切り，それらが手にする花綱 が弧を繰り返して室内を取り巻いている。オルトスタットの上にはいくつかの装飾帯を 隔てて，柱間ごとにピナクス（両側に扉のついたパネル画）が表わされている。ピナ クスには，人物群像と静物が交互に描かれている。南壁（右側壁）では手前側から，サ テュロスの饗宴, ニワトリと籠に盛った果物と夕オル, 哲学者と入信者らしい女性とカ ロン (「秘儀入信者は死に脅かされない」の意? ?), ブドウと野菜類, 書板に (ディオニュ ソスの勝利を？）記入するウィクトリア，と連なっている。東壁（奥壁）の南側 (右側) のものには魚が，北壁（左壁）の西端（最も手前側）のものには座した女性と奏楽の女 性たち（アリアドネの結婚の物語？）が描かれ，そのほかは欠損している。活気ある人 物を空間の広がりの中に配したピナクスと，静物のモティーフを近接した視点で描いた それとが交替して，奥行きの深い部屋の壁面にリズミカルに繰り返されている。人物群 像のピナクスは全般にディオニュソスの秘儀に関する場面らしく, 饗宴の場にふさわし い主題である。

これに隣接する「サチェッロ・イリアコの家」（I 6，4）では，玄関脇の東西に長い矩 形プランの部屋 $\mathrm{c}$ に第四様式初期の壁画があり, 各壁面の中央と両脇にパネル画が表わ されている。長辺側では, 奥壁にあたる北壁で, 中央にイチジクの枝や果実と死んだ若 鷄，両脇にそれぞれ銀の容器類を描いたパネル。南壁（その西端に出入口がある）は画 題不明。短辺側では，東壁の中央に枝つきのザクロと嘴を縛られた死んだ鳥。西壁の中 


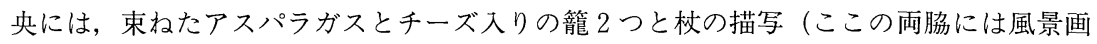
のパネルがある）となっている。それぞれの壁面は, 中央がやや大きめの静物画パネル で占められ, 両脇には風景画や食器類の描写の小パネルが位置している。部屋の形状と 広さから，ここは食事室（トリクリニウム）とみられるが, 壁画の主題もさまざまな食 材のヴァラエティを含んでいる。

ポンペイのパラエストラ付近にあるいわゆる「魔術の儀式の建物」(Complesso di riti magici, II 1, 12) では, 玄関脇の矩形プランの部屋 3 の壁面（図 3 ）に, 第三様式で静 物画が連続的に描かれている。出入口がある短辺側の東壁を除く三方の壁面に壁画が 残っているが, それぞれオルトスタットの上方に, 白地を細線で区切ることで横長矩形 のパネルが表わされている。南壁（左壁）では手前から, ザクロの実, 倒れた籠からこ ぼれるナツメヤシ，四肢を縛られて仰向けに寝かされた猪，と続き，西壁（奥壁）では， 白鳥（？）と松明を 2 本もたせかけた把手つきの籠， 2 杯のイカと 2 尾の魚（1 尾は口 と尾が紐で結ばれている), 北壁 (右壁) では奥から順に, ブドウの房, 空による欠損部, オウムと果物，と続いている。食肉用の動物や魚介類，果実といったさまざまな食材に 加えて, 儀礼の道具（松明）や珍鳥が表わされている。南壁の奥に寝台の一部が残り, 床面に食卓の位置を示す切石装飾があることから，ここも食事室（トリクリニウム）で ある。

ヘルクラネウムの「仔鹿の家」(IV 21) から出土した一群の静物画も, 食事や饗宴と の関係が濃厚である。ブルボン朝時代に発掘され, 現在はナポリ国立博物館に伝わる 8 枚の静物画パネルが飾っていたオエクス XXIX をみてみよう。ここでは南側の主要な出 入口に加えて，西側にも小さな出入口があり，北壁の中央に開いた空からは庭園への眺 望が得られた。壁画は赤色の腰羽目と青色の中間部を基調としている。出入口や空があ る南北壁を除き，東西の両側壁では中間部の中央にやや大きいパネル画（各辺が $60 \mathrm{~cm}$ 強）があり，またすべての壁面でその両脇の部分にやや小さいパネル画（各辺が $37 \sim 41$ $\mathrm{cm}$ 程度）が位置していた。壁面から切り取られて博物館にあるパネル画は, 当初の配 置を確定するのが困難である。しかしやや大きめの 1 枚 (MN inv.8644 A) (図 4 ) は, 側壁の中央にあったもので（陰影のつけかたから東壁のものだろうか？）, 画面の左手に 木立と有髭のディオニュソス神の立像が描かれ，手前にはカンタロスと山羊の頭とオイ ノコエが，後方では丘状の盛り土に松笠や果物籠をのせた把手つきの皿が置かれている。 いっぽう，7枚の小パネルにはすべて静物のモティーフが描かれている。それらは, ブ ドウを喰む鬼と壁に掛けられた死んだ鳥とリンゴの実 (inv.8644 C) (図 5 )，水鳥とガラ ス容器を逆さに被せた陶製オイノコエ (inv.8644 $\stackrel{(11)}{\mathrm{A}}), 3$ 羽の鵣とマッシュルーム (inv. 8647 C $) ， 2$ 羽の鵣とウナギ（それともウツボ?）を前後に配したもの（inv.8647 D) (図 
(13)

6 ), 吊された鵣と枝つきザクロとリンゴ (inv.8647 B), 三叉戟を差した金属製の舞の把 手にカワセミがとまり, まわりに貝, エビ, イカを散りばめたもの (inv.8644 (14) , 羽根 をむしられ逆さに吊された鳥と, 前肢の 1 本で吊られた死んだ鬼 (inv.8647 A) (15) で, 山 野や農園, 海浜などでとれる静物のモティーフのさまざまなレパートリーが尽くされて いる。死んで仰向けになった鵣と魚や，吊されたり羽根をむしられたりした鳥や兔は， 調理を待つばかりの食材である。

同じ家の隣接するオエクス XXXにも，オルトスタットに静物画のパネルが連ねられ ていた。開口部の大きい広い部屋であるため壁画は損傷がひどく, 部屋の西北隅の部分 がわずかに古い写真で確認される。これをみると, 西壁北端のパネルにはチーズか小麦 入りの袋をのせた皿と, 斜めに置かれたぺドゥムと 2 つの円筒形の籠, 北壁西端のパネ ルには果物の入った籠などが表わされていた。

\section{II. そのほかの空間の例}

アトリウムやペリステュリウムのような通行や共用のための空間にも，静物画の連続 的な配置がなされた例がある。

ポンペイの「パクウィウス・プロクルスの家」(I 7, 1) のアトリウム 3 ア 3 では, 北側に あるウェスティブルムからの開口部からみて, 左壁（東壁）と奥壁（南壁）の左（東） 端に第四様式の壁画が残存している。東壁には, アトリウムの周囲に通常配される諸室 への開口部を模して, 壁壟状の凹部が 3 つ設けられている。それらの間隙にある壁面 ( 2 つ）と, 部屋の両端の部分（北側に 1 つと南側に 2 つ）とで, 合計 5 つのオルトスタッ ト・パネルが表わされているが，それらは立関側から交互に黄と赤で塗り分けられ，そ のそれぞれには中央はヴィネット状の枠縁を欠いた静物画が描かれて，地色の上へ浮か びあがるように表わされている。東壁の北端（黄色）には口を縛られた 2 尾の魚, 最初 の壁蘢と 2 番目の壁蓖の間隙部 (赤色) には果物を盛ったガラス鉢, 次の間隙部（黄色） にはオイノコエとこれに立て掛けた円盾, 第 2 の壁鴿のすぐ南（赤色）にはイカ, 壁面 の南端（黄色）には鳥とサクランボが表わされている。壁面を折れ曲がった先の南壁東 端部のオルトスタット (赤色) には，1頭の山羊が馸ける様子で描かれている。開口部 による中断の多い長大な壁面を処理するという, 装飾構成上の実際的な問題が, 黄色と 赤色のパネルを交互させ，これにさまざまな種類の静物画を描いて繰り返しのリズムを 与えることで解決されている。しかしアトリウムは最初に賓客を迎える空間でもあるの で,ここへ描かれる装飾主題の選択には, 後述するように空間の社会的機能に即した配 慮も読みとるべきだろう。

長大な壁面の処理という点では, ペリステュリウムにも同様のことが考えられる。ポ 
ンペイの「ウェス夕聖女の家」(VI 1，7）のペリステュリウム39では，ジュゼッペ・キア ンタレッリによる1803年のスケッチが，現在は褪色のひどい壁画の当初の状態を伝えて いる。開口部による中断を伴わない西壁がよく記録されているが，ここでは壁面の中間 部が円柱で区切られ，柱間にはピラスターとコーニスからなる建築モティーフが描かれ て，その上にさまざまなしかたで扉を開いたピナクスが表されている。ポンペイの「ク リプトポルティコの家」の例に似て, ここに種々の静物画が描かれている。装飾構成に は第二様式を思わせるところがあるが，一般には第四様式における復古的作例とみなさ れている。左側から順にみてゆくと，第 1 画面では牛の頭部と何かが燃やされている祭 壇, 第 2 画面ではニワトリとフットボール状の物体, 第 3 画面では死んだ鳥と樹木の枝 と把手つき壸や蓋つき小箱などのさまざまな容器や道具類, 第 4 画面ではエビと魚, 第 5 画面では 1 羽のアヒル, 第 6 画面では果物をかじる鬼と吊された鳥, と並んでいる。 北壁の西端部を記録した別のスケッチにも，ブドウやザクロや籠に盛ったイチジクを表 わしたものや，水鳥や死んだ鳥を描いたものが認められる。さまざまなモティーフが寄 せ集められて長大な壁面に配されることで，廊下を歩く人は歩みにつれて次々と継起す る主題の変化を楽しむことができたに違いない。

ポンペイの「ディオスクーロイの家」(VI 9，6-7) では，2つのアトリウムを中核とす る領域が広大な敷地の南北を占め, それらの間の中央部には広い庭園が設けられている。 これをぺリステュリウム53が取り囲み（図 7 ），その東側にはオプス・セクティーレで豪 奢に壁面を飾ったオエクス 46 が隣接している。ペリステュリウムもこれに接する東辺で は廊下の丈を高くし，床面の舗床モザイクに特別な図柄を施して強調が行なわれている。 またこの部分では円柱列が省かれていて，オエクスからぺリステュリウム内の庭園や池 に向けての眺望を楽しむことができた。第四様式によるぺリステュリウムの壁画は，張 られた幕のような黄色の領域を中間部に一定間隔で配し, その間吵に奥行き感のある建 築モティーフがあてられている。静物画を表わしたピナクスが，ここにひとつずつ描写 されている。欠損や褪色で判読できないものも多いが，北側柱廊の壁面には，イチジク を盛つた籠とこれをついばむ鳥のパネルや, 横たわる 2 頭のアンテロープの前に花綱を 盛った籠やアヒルのあるパネルが認められ，西側柱廊の壁面にも鳥や果物を表わした画 面が見分けられる。これらの静物画は，オエクス46を中心にして組織されたこのあたり の区画の機能と関係しているように思われる。

ポンペイの「エフェボの家」(I 7, 11) では, アトリウムA”に接するやや広い矩形プ ランの部屋10がトリクリニウムと考えられるが，ここにはオルトスタットの並びのほか に格別な絵画的主題は描かれていない。むしろこれに隣接して, こことアトリウムに出 入口をもつ小室11（図８）に静物画の小パネルが並んでおり，これは食事室に附属して 
設けられた休賏室（クビクルム）とみなされる。両室とも壁画は第四様式によっている。 クビクルム11では壁面の中央に建築モティーフによる眺望を描き，その両側がオルトス タット状の区画となっている。ここの中央に描かれた静物画の小パネルは，北壁の東側 に2つのザクロの実と鳥を描いた画面（西側はアトリウムへの出入口になっている），東 壁の南側にはリュトンと豹とカンタロス（北側はトリクリニウム 10 のの出入口）, 南壁で

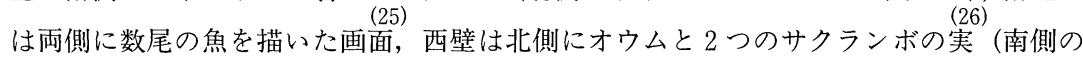
は欠損）となっている。さまざまな食材と酒神の関連品が含まれており，食後の休息の 場所であることを窥わせる。

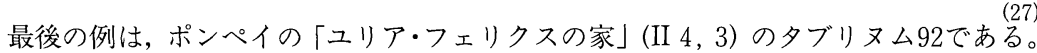
これはアトリウム93の東側に位置し，奥壁（東壁）の中央にある広い空から庭園への眺 望が望まれた。壁画の主要部分はブルボン朝時代の発掘で剥ぎ取られ，現地に残る部分 は褪色と破壊が進んでいる。とくに北壁と東壁は荒廃しているが，南壁は腰羽目以外の 部分がまとまって剥がされたため, ナポリ国立博物館でその原状をよく伝えている (MN inv.8598)（図 9 )。これをみると, 上部のフリーズ状の区画が 4 つの横長矩形パネルに分 けられ，各々に静物画が描かれている。ポンペイの「魔術の儀式の建物」のそれ（図 3 ) に似た構成である。左から順に，さまざまな種類のパン，生き生きとした魚たち，金属 製の容器と皿に盛った卵と吊した鳥とタオルなど, 貨幣の山とこれが入った袋や筆記具 類, と続いている。また, 北壁からとみられる別の静物画パネル 2 枚も保存されており (MN inv.8611)，ひとつにはブドウ酒の入った杯の後方に七面鳥が横たわっていると (30) (31) ころ。他方には果物が入ったガラス鉢, アンフォラ，果物入りの壹が表わされている。 タブリヌムという場所からか, 筆記具や貨幣の堆積の描写が注目される。食糧としての 山野の動物や家禽類と魚, ブドウ酒をなみなみとたたえた容器, 山盛りの果物鉢などは, この家の主人の財力や家産の豊かさを象徵するかのようである。

\section{III. 諸作例の特徵}

さて，これまでに列挙してきた作例には，宴の材料となるような動物や農産物，道具 類が多く含まれていた。動物の中には生命感と敏捷性を示すものもあれば，死んでぐっ たりした状態のものもある。紐で縛られたり釘や環で壁に吊された鳥や魚や小動物は, 捕らえられて調理されるのを待つ食材の姿を示しているし，中でも羽根をむしられて丸 裸にされた鳥はそのことを強く印象づける。果物が籠や透明なガラス鉢に盛られた様子 や，ブドウ酒を飲むための容器と杯，ふかふかのパンや血に盛られた白いゆで卯などは， 食卓の上で日頃繰り広げられていた光景が, 絵筆によってそのまま画面へ定着させられ たものであることを感じさせるだろう。 
こうした静物モティーフは，室内装飾の全体構成の中では，パネルやタブローを模し て枠取られた画面や，無地の背景に浮かび上がるヴィネットとして表わされ，さまざま な場所に配されている。それらはひとつずつ孤立して扱われることも多いが，本稿でみ ているように，さまざまなヴァラエティが寄せられてひとつの空間の中に集約され，連 続的に扱われる場合もある。

それらの配置のしかたには, ピナクスの並ぶ様子を再現した例（「クリプトポルティコ の家」(図 2 ), 「ウェス夕聖女の家」,「ディオスクーロイの家」(図 7 )) や, 横長矩形の 画面を壁面上部に連続させたもの（「魔術の儀式の建物」(図 3 ),「ユリア・フェリクスの 家」(図 9)), 壁面中間部やその上方にあるパネル画やタブローを模したもの(「仔鹿の家」

(図 4, 5, 6), 「サチェッロ・イリアコの家」,「パクウィウス・プロクロスの家」,「エフェ ボの家」(図 8 )) などがある。

また配される場所は, トリクリニウムやオエクスのような食事や饗宴のための部屋が 多い（「クリプトポルティコの家」(図2)),「サチェッロ・イリアコの家」,「魔術の儀式 の建物」(図 3), 「仔鹿の家」(図 4,5，6))。しかしもちろん, 部屋の機能については, 家屋の全体の中でさまざまな手がかりを捉えて個別の事例ごとに特定しなければならず， 建物の全体の中での部屋の位置や, プランの相対的な広さ, 室内装飾に主室部と給仕空 間への分節があること，クリネ（横臥用寝台）の痕跡 (cf. 図 3 ), 室内装飾の主題や構 成のしかたといった諸要素を手がかりに，そのいくつかを通じて総合的に判断されるも のである。

そのほかの空間, たとえば「ディオスクーロイの家」のペリステュリウム53は, 隣接 するオエクス46の展開部分である（図 7 )。静物画は，ここを食事室の延長と考えること で解釈が容易になる。来客が招かれて行く通路となり, 逍遥のための路となり, 大宴会 のときにはオエクスをあふれた人のための場所にもなる。同じようなことが,「エフェボ の家」のクビクルム11 (図 8 ) にもあてはまる。これは隣接するトリクリニウム 10 と密接 な関係にあり, 食後や宴の途中での休㮩に適した位置にある。したがって, ペリステュ リウムやクビクルムでも, 隣接する饗応の場と関連して, その延長部分として用いられ ることがあるから, 静物画と部屋の機能の関係については慎重な判断が必要である。

また「パクウィウス・プロクルスの家」や「ユリア・フェリクスの家」(図 9 ) のよj に，アトリウムやタブリヌムに静物画が連続的に描かれる場合もある。こうした空間は 直接に饗応の機能と関連するわけではないが，これらは邸の主人が賓客を最初に迎える 場である。したがってむしろこれは, 主人の来客に対する一般的な態度を表明する場所 に，饗応を喚起するモティーフを用いたものと理解できるだろう。「ユリア・フェリク スの家」のタブリヌム（図9）では，この場所にふさわしく大地の産物の表現とならん 
で帳簿用の筆記具や貨幣の堆積が表わされており，主人の社会・経済活動のさまざまな 側面が集成されている。

なお「ディオスクーロイの家」(図 7 ) のような，いくつかの空間にまたがって装飾が 構想されている例があるように，壁画やモザイクの主題を決定するには邸宅の全体の統 御者であるその家の主人の関与が不可欠である。饗応の間やアトリウム，タブリヌムな どに配された静物画は，賓客を迎え，家産の豊かさを示して，歓待の意を表明すること にその象徴的役割がある。こうしたことはその家の主人の意向を体して決めなければな らず，実際の制作担当者が主題を気ままに選んだ可能性はむしろ少ないのではなかろう か。

\section{IV. 静物画を連ねることの意味}

種類の異なる複数の静物画を連ねることに，どのような意味があったのだろうか。冒 頭で述べたように，ギリシャ・ローマの饗宴は，神々への感謝のしるしとしてさまざま な儀礼を伴うのが常であった。ポンぺイ壁画の中にもその痕跡を認めることができる。 上述の諸例の中でも,「仔鹿の家」のオエクス XXIVの壁画では, 側壁の中央にあった大 きいパネルに，神域を暗示する木立の前にディオニュソスの像が立てられ，松笠やカン タロス, 山羊の頭部といった，神話や祭祀を思わせるモティーフが描き込まれている(図 4 )。また，「ウェス夕聖女の家」のペリステュリウムを飾っていたピナクスの中にも， 犠牲獣とみられる牡牛の頭部と, ものが燃やされて炎や煙をあげる小さな祭壇が含まれ ていた。

こうした情景が単独に表わされたものとしては，冒頭で述べたようにボスコレアーレ (39)

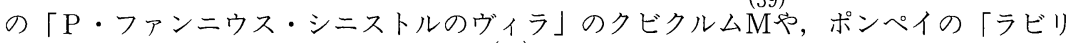
ントの家」(VI 8-10) のオエクス43(図 1)，「ユリア・フェリクスの家」出土の壁画断片 （ナポリ国立博物館 inv.8594）などに描かれた，神祠や祭壇の前に果物や鳥，小動物， 魚が捧げられた情景があった。第二様式以後ではこれらにも次第にパネル画やタブロー のような枠縁が与えられ，周囲の部分から切り離されてひとつの画面の中に収束して いつた。

1 枚のパネル画のようになることで扱いやすくなった静物表現は，いくつか連ねられ ることでモティーフのヴァラエティの多様さと変化の妙を表わす手段になった。動物・ 植物・鳥類・魚介類が対照され，山野や海の野生動物と家禽が集成されている。捕らえ られたばかりの生物がいるかと思えば，すでに死んでぐったりしているものもあるし， オウムのような珍鳥から，羽毛を剝がされて丸裸になった鳥までが集められている。多 様なヴァリエーションを対比させ，壁面に豊かな表情を与えるこうしたことは，伝統に 
遡る祭祀性のみから説明できるのではなく, 種々のモティーフの集成に対する博覧的・ 審美的な関心の増大を反映しているように思われる。

ところでローマ時代の静物画にも，それが十分に鑑賞の対象となるだけの表現上の工 夫が凝らされている。透明なガラス鉢をはじめとして，さまざまな物質の材質感が巧み に表わされていることはよく知られているが, 構図についても, 雛壇状に空間をしつら えてその中にモティーフを配することで変化が持ち込まれている。「仔鹿の家」のあるパ ネル（inv.8644 C）（図 5 ）では，前景に横たわる鬼の体軀に対して，立ち上がったその 耳や吊された鳥が垂直性を加えて，画面奥のL字形の空間の窪みをなぞっている。別の パネル（inv.8647 D）（図6）では，次々と垂れ下がる鳥の首やウナギの頭と尾が，画面 に反時計回りの旋回のリズムを与えている。また別のパネル (inv.8647 C) では, 手前へ 斜めに張り出した 1 羽の鳥の後部の動きが前景のマッシュルームへと伝わり, 雛壇の段 差で隔てられているにも拘わらず後景と前景が時計回りの旋回のリズムで結びつけられ ている。「ユリア・フェリクスの家」のあるパネル（inv.8611，右側）では，左下の小さ いモティーフ（ザクロ，リンゴ，壼の蓋）と右上の大きいモティーフ（果物入りのガラ ス鉢，アンフォラ，壼）をひとつずつ組み合わせた単位が 3 度繰り返されているし，全 体の構図は雛壇が作る逆L字形の段をなぞっている。同じ家の別のパネル (inv.8598, 右 から 2 番目）(図 9 ) では，冷たい質感をもつ金属製品とそうでない柔らかい質感のもの が交互しており，それぞれが $1: 2: 1: 2$ のリズムをなして, 右方に向かうにつれて三角 形の構図が次第に開いて行く。こうしたさまざまな描写上の工夫が, 審美的観点からの ものでないとすれば，いったいどのように考えたらよいのだろうか。異なる質感や生命 感の対比や，色彩・構図の対照といった個々の画面で行なわれる表現上の配虑は，連続 的に扱われた静物画の集成ににおいてとくによく発揮されている。

しかしさきにも見たように, 静物画の連続が饗応のための部屋やアトリウム, タブリ ヌムなどに集中していることから，描かれたモティーフの多様性がその邸宅の家産の豊 かさを象徴するのにも役立てられていることがわかる。さまざまな大地や海の恵みと， それが容器や血にうず高く盛られている様子は，この家が扱う資産の豊富さを伝達しよ うとしているかのようである。多様な種類の静物画を連続的に配置することには，この ような観点をも加えて考えるべきではなかろうか。しかし逆にいえば，それらが迎賓や 饗応の空間に描かれた場合は，来客をもてなす際の気前のよさの表明にも通じていると いえる。潤沢な家産に支えられたホスピタリティの明示は, ウィトルウィウスやマルティ アリスによって伝えられた「クセニア」という言葉の語義にも通底する。このように考 えたとき, 静物画の主題は社会的機能を帯びてくるのであるが, とりわけそれらがひと つの壁面に連続的に扱われた場合には, ヴァラエティの豊かさと対比の妙によって, こ 
の機能が一層有効に働くのである。

\section{V.むすびにかえて：静物画の連続配置のその後}

連続構図による静物の表現は, ポンペイ以後の室内装飾においてどのような展開を辿 ることになるのだろうか。

ローマ郊外のトッレ・デ・スキアーヴィで発掘され，ヴァティカン博物館に収蔵され た舗床モザイク（図10）では，グリッド状の構困の中にさまざまな種類の静物画が描か

れている。技法の違い（フレスコ画とモザイク）にもよるが，こちらは構図が簡略で, ひとつひとつの画面の中には，モティーフを少数の種類に絞って大きく表わしているこ とが多い。詳述するゆとりはないが，個々のモティーフには描写の細部にわたるまでポ ンペイ壁画のそれとの共通性が多く，なかば常套的になっていたモティーフ・レパート リーが，そのまま継続しているような印象を受ける。ここではまだ，左下の魚の図と上 端中央のイカとエビの図に，ポンペイ壁画でしばしばみられた雛壇状の台による空間構 成の名残が認められるが, 奥行き感のある空間にモティーフを複雑に配したポンペイ壁 画と比べると，さまざまなモティーフを判然と提示するために，表現がより単純で直截 的になってきている。

同様に北アフリカの領主の邸館を飾っていた舗床モザイクでも，グリッドの中の空間 性を捨象された無地の背景に，モティーフのみが明示的に描かれている。互いに形態の 区別がつきやすい端的で図式的な表現は，モティーフのヴァラエティそのものを提示す るのに重点が置かれていることを示している。それらは床の上に広がる単一の画面の中 に隣り合って描かれているため, 何らかの見本帳の中のぺージでもあるかのように,くつ きりと例示的に表わされている。

このように，ローマ時代における静物画のモティーフは，本来の祭祀的性格と審美性， および富裕とホスピタリティとを示す社会的機能をあわせもちながら，描かれる場の性 質に応じて多様な展開を遂げてきた。しかし長い時代にわたる変遷を通じて大局的にみ るとき，その背景にはやはり常に大地や海の恵みに対する讃美の気持ちが湛えられてい るように感じられる。この射程をさらに先へとのばすなら，シリアやヨルダンで多数発 掘されている初期キリスト教会堂の舗床モザイクにも，大地や海の擬人像とともに自然 がもたらす種々の産物や季節の労働の姿が集成され，博覧的なしかたで表わされている ことが思い起こされる。

飛躍を恐れずにあえて述べるならば，キリスト教時代にもなれば，こうしたさまざま な静物画を描く伝統が，おそらくは聖餐の秘蹟をめぐる神学について表現の可能性を深 め，また被造物の讃美のような宇宙論的な思惟に対して展開の場を与えて行ったのだろ 
(46)

う。教会堂の装飾体系の形成過程を考える際に, 共同食事という観点を用いた論考はま だあまり多くないように思われる。しかし神のわざを讃え，感謝を捧げる典礼でさえも， 古代の饗宴の祭祀性に遥かな淵源をもち，それがローマ時代を通じてそのほかのさまざ まな機能をあわせながら，豊かな内容をもつまでに発展してきた面のあることを考えて はいけないらろうか。自然の恵みに対する感謝の表明は，地中海世界に限ってみても時 代を越えて受け継がれ，さまざまな美術表現の機会においてその姿を現わしている。本 稿は，ポンぺイなどの室内装飾を通じてその一端を垣間みようとした試みである。

\section{文献略記}

Croisille 1965 : J.-M.Croisille, Les natures mortes campaniennes, Répertoire descriptif des peintures de nature morte du Musée National de Naples, de Pompéi, Herculanum et Stabies, Bruxelles, 1965.

PPM: Istituto della Enciclopedia Italiana, Pompei, pitture e mosaici, Roma, 1990-. Piccirillo 1993: The Mosaics of Jordan, 1993, Amman.

Tran Tam Tinh 1988: Tran Tam Tinh, La Casa dei Cervi a Herculanum, 1988, Roma.

Xenia 1990: C.Balmelle et alii, Recherches franco-tunisiennes sur la mosaïque de l'Afrique antique, 1, Xenia, 1990, Rome et Paris.

『ポンペイの壁画』1991：ジュゼッピーナ・チェルッリ・イレッリ，青柳正規，ステーファ ノ・デ・カーロ, ウンベルト・パッパラルド編, 『ポンペイの壁画 ヴェスヴィオ火山 で埋没した地域の壁画集成』1-2, 岩波書店, 1991.

注

（1）アクロコリント中腹の共同食事の施設（N. Bookidis, Ritual dining at Corinth, in N.Marinatos, R.Hägg ed., Greek Sanctuaries-New Approaches- , 1993, London, pp.45-61) や, アテネの南のストア (J. M. Camp, Die Agora von Athen, 1986, Maintz,pp.138-143) などが発掘されている。古代ギリシャの国家祭祀としての饗宴 をまとめた研究は, P.S.Pantel, La cité au banquet, Histoire des repas publics dans les cités grecques, 1992, Paris/Rome.

（2）現代美術では，静物は純粋に造形表現のための素材であること多いが，古代のそ れにはさまざまな象徵的含意を認める意見が多い。ポンペイの静物画に神々への奉納 物としての性格を指摘した K.Schefold (traduction de J.-M.Croisille), La peinture pompéienne, Essai sur l'évolution de sa signification, 1972, Bruxelles, pp.62-63 以 来，多くの議論があるが，それらは例えば Croisille 1965, pp.11-16などにまとめられ ている。

（3）静物画の定義の問題については, Croisille 1965, pp.5-7や, ステーファノ・デ・ カーロ「ポンペイ壁画の二つのジャンル一静物画と庭園画」『ポンペイの壁画』1, pp. 
270-280の pp.270-271 を参照。このジャンルの概括的記述としては, R.Ling, Roman Painting, 1991, Cambridge,pp.153-157。様式変遷については H.G.Beyen, Stilleben aus Pompeji, 1928, 's-Gravenhagen を参照。

（4）詳細は PPM, vol.I, pp.250-273; 『ポンペイの壁画』2, pp.18-19を参照。

( 5 ）『ポンペイの壁画』 $1, \mathrm{pl} .3$.

(6) 『ポンペイの壁画』1, pl.2; Croisille 1965, fig.136.

（7）『ポンペイの壁画』2, fig.5c; R.Ling, Roman Painting, 1991, Cambridge, pl. $\mathrm{XB}$.

（8） PPM, vol.I, pp.282-291; 『ポンペイの壁画』2, 1991, p.21 と p.18のプランを 参照。東壁中央のパネルは Croisille 1965, fig.93にもある。

(9) 家の名称はサバツィオス神などの祭祀具が発掘されたことによる。パラエストラ に近いことから，トラキア地方出身の剣闘士の関与が指摘されている (PPM vol.II, pp.19-20)。トリクリニウム 3 は ibid. pp.22-37 を参照。

(10) この家のモノグラムが Tran Tam Tinh 1988 で, オエクス XXIX は pp.68-73 に 記述がある。

(11) Tran Tam Tinh 1988, fig.129; Croisille 1965, fig.158 左.

(12) Tran Tam Tinh 1988, fig.130; Croisille 1965, fig.141.

(13) Tran Tam Tinh 1988, fig.132; Croisille 1965, fig. 140.

(14) Tran Tam Tinh 1988, fig.133; Croisille 1965, fig.158 中.

(15) Tran Tam Tinh 1988, fig.134; Croisille 1965, fig. 149.

（16）Tran Tam Tinh 1988, fig.137（現状），fig.138（旧状）.

(17) PPM vol.I, pp.486-503; プラン は Guida Archeologica di Pompei, 1976, Verona, p. 210 にも掲載されている。豪華な舗床モザイクで著名である。

(18) PPM vol.IV, pp.26-32, 西壁のスケッチは ibid. fig.44 a p.27, 北壁のは ibid.

fig. 45 a p.28 および Croisille 1965, fig.229.

(19) PPM vol.IV, pp.956-974.

(20) PPM vol.IV, fig.203 a p.967; Croisille 1965, fig. 139.

(21) PPM vol.IV, fig.204 a p.964, fig.207 a p.965; Croisille 1965, fig.167.

(22) Croisille 1965, fig.230.

(23) $P P M$ vol.I, pp.648-649.

(24) $P P M$ vol.I, pp.650-656; 『ポンペイの壁画』2, pp.32-33.

(25）『ポンペイの壁画』1, pl.14

(26) 『ポンペイの壁画』1, pl.15

(27) PPM vol.III, pp.286-291.

(28) Croisille 1965, fig. 193.

(29) Croisille 1965, fig.208.

(30) Croisille 1965, fig. 107. 
(31) Croisille 1965, fig.36.

（32） ポンペイ壁画の静物画に描かれた動物が，食材として調理される過程のものであ ることは，拙稿「クセニア画の縛り紐と鳥籠のモティーフについて一小動物の描写に おける意味の転換一」『岡山市立オリエント美術館研究紀要』14, 1996, pp.25-58でも 触れた。

(33) 一般に, 複数の寝台 (クリネ) が置かれて会食されるトリクリニウムやオエクスの ほうが，ひとつか 2 つ寝台を置くクビクルムよりもプランが大きくなる。

（34）室内空間が巽なる機能を担う別個の部分に分かれていることを，舗床モザイクや 壁画装飾の構成を変化させることで示す方法。このとき空間は一様に連続している場 合もある。一般に食事室なら主室部が広く取られ，寝室なら前室部が広い。

（35）大規模な饗宴において，奥の部屋で主人と重要な賓客が池や水路を見遥かしなが ら宴をはり，池を囲む庭園や回廊に多くの下位の列席者が並ぶ様子は，E.S.P. Ricotti, The Importance of Water in Roman Garden Triclinia, in Ancient Roman Villa Gardens, Dumbarton Oaks Colloquium on the History of Landscape Architecture X, 1987, Washington D.C., pp.135-204 で提唱された, ティヴォリの ヴィラ・アドリアーナなどで行なわれた皇帝主宰の宴の復元案を思わせる。

（36）食事室に附属するクビクルムの類例は, E.S.P.Ricotti, op. cit.の中の fig. 1 の $\mathrm{f}$ (小プリニウスの別荘の復元) と fig.13の f (ヴィラ・アドリアーナのカノープス) を参照。

（37） 共和政期ドムス住宅の構造と社会的機能については, J.R.Clarke, The House of Roma Italy 100 B.C.-A.D.250, Ritual, Space, and Decoration, 1991, Berkeley, pp. 1-29 に簡潔な説明がある。タブリヌムは, 部屋の機能が未分化であった早い時代には 饗応の場を兼ねていた（ibid. p.13）。

（38）静物画とホスピタリティの関係については, J.-P.Darmon, Nymfarum Domus, Les pavements de la maison des Nymphes à Néapolis (Nabeul, Tunisie) et leur lecture, 1980, Leiden, pp.152-153 にも同様の説明がある。

（39）前室部とアルコーヴの各々の側壁における中央部分の描写（M.Anderson, Pompeian Frescoes in the Metropolitan Museum of Art, The Metropolitan Museum of Art Bulletin, winter 1987/88, figg. a pp.22, 23)。

(40)この部屋の詳細な記述は, V.M.Strocka, Casa del Labirinto (VI, 8-10), Häuser in Pompeji 4, 1991, München, pp.44-48, figg.286-312.

(41) S.De Caro, Il Museo Archeologico Nazionale di Napoli, 1994, Napoli, fig.149.

(42) Vitruvii, de Architectura, VI, 7, 4; Martiarii, Epigrammata, XIII. しかし静物 画にはりュパログラフォス（くだらないものの画家）の伝承もあり (Plinii, His. Nat. XXXV，112)，一概に歓待の意とせず，状況に即した解釈が必要である。

（43）制作年代は 4 世紀初頭とされる (C. Balmelle, Images de mosaïues à Xenia hors de Tunisie, Xenia 1990, pp.51-66, n. 54)。 
（44）例えば, トゥブルボ・マイユス出土モザイク (バルドー美術館蔵, Xenia 1990, fig. 6 a p.16, ティムガドのカピトリウム北側の建物の広間から出土したモザイク (ibid. fig. 63 a p.62), エル・ジェム出土の「サイコロ遊びのモザイク」(バルドー美術館蔵 inv.3197, ibid. pl.XIII) などが主要なものである。北アフリカでも四季の擬人像や季 節の労働の姿が搟入され，次第に象徵的な描写の占める割合が優勢になってくる。

（45）例えば，海の擬人像のあるマダバの聖使徒教会 (578年, Piccirillo 1993, pp.96-108), 大地の擬人像と産物, 奉献の主題を描いたネボ山の僧ヨハネの礼洋堂 (565 年, Piccirillo, 1993，166-175)，側廊に静物を配し身廊を季節の労働と都市の描写で埋 めたカストロン・メファアの聖ステファヌス教会 ( 8 世紀, Piccirillo, 1993, pp. 219, 238-239）などの例をあげておこう。

（46）辻佐保子『古典世界からキリスト教世界へ一舗床モザイクをめぐる試論一』, 1982 年, 岩波書店, における特に IV (身廊部の主要な装飾レパートリー) とVの 2 （「天地 創造の讃美」) の論点を踏まえながら，5８世紀頃の東地中海域に多く残る教会堂の 舗床モザイクの装飾体系について別稿で検討したい。

付 記

本稿は第 5 回ヘレニズム・イスラーム研究会 (1998年 7 月 5 日, 金沢大学) での口頭発 表を骨子としている。主宰の佐々木達夫・岡田保良両先生はじめ, 出席の諸先生方より ご指導を賜わりました。 


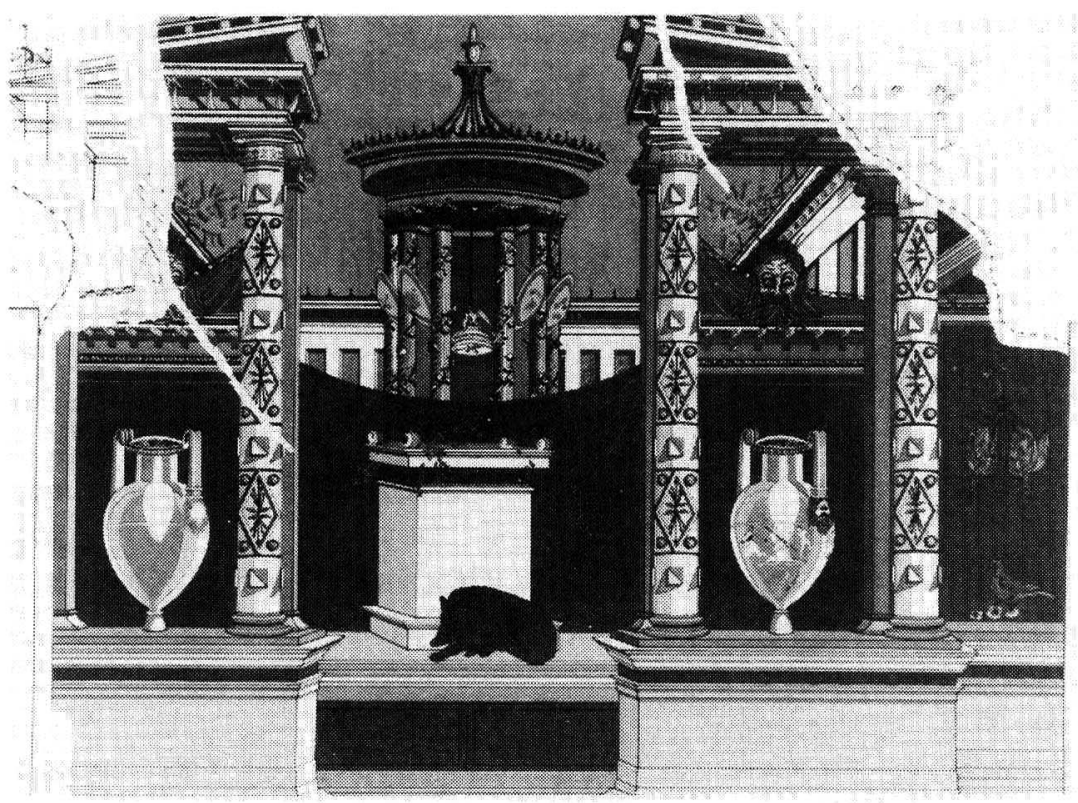

図 1 (出典：V.M.Strocka, Casa del Labirinto(VI, 8-10), 1991, München,fig.292.)

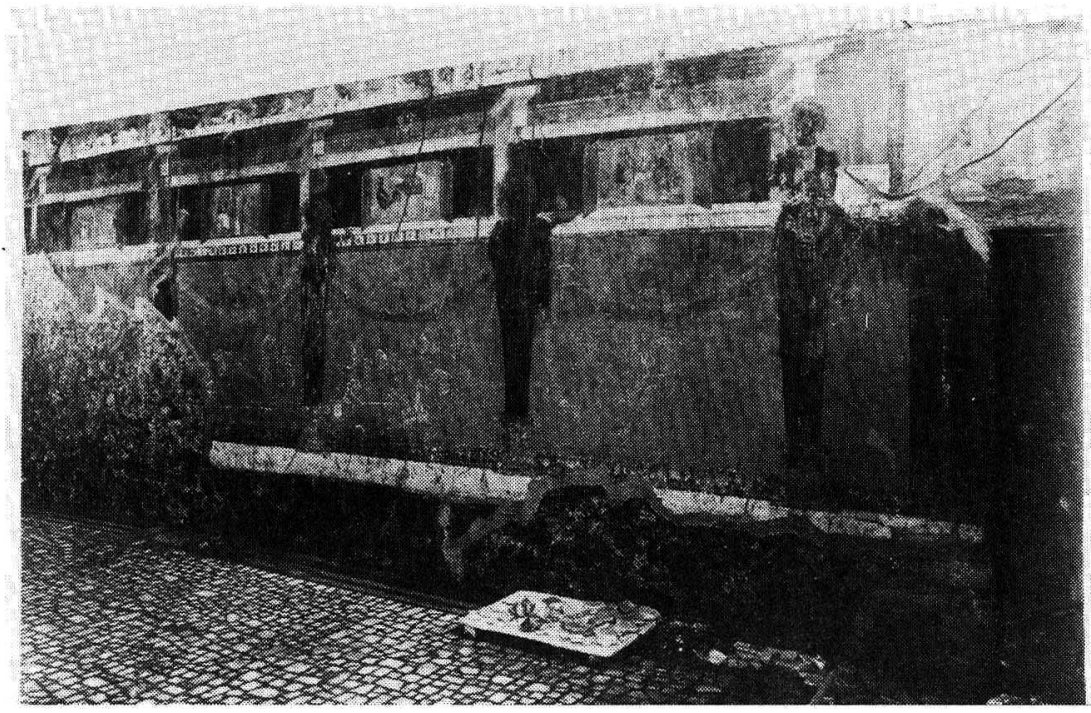

図 2 (出典: $P P M$ vol.I, fig.122 a p.260.) 


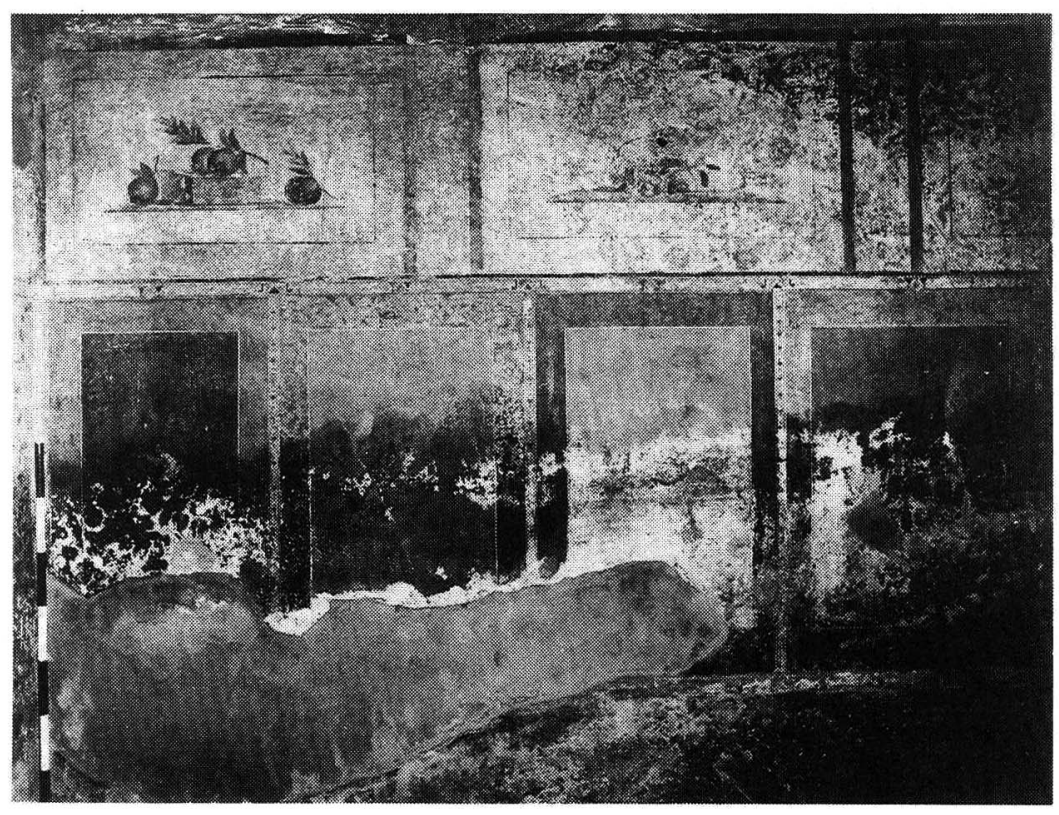

図 3 (出典: $P P M$ vol.III, fig.4a a p.22.)

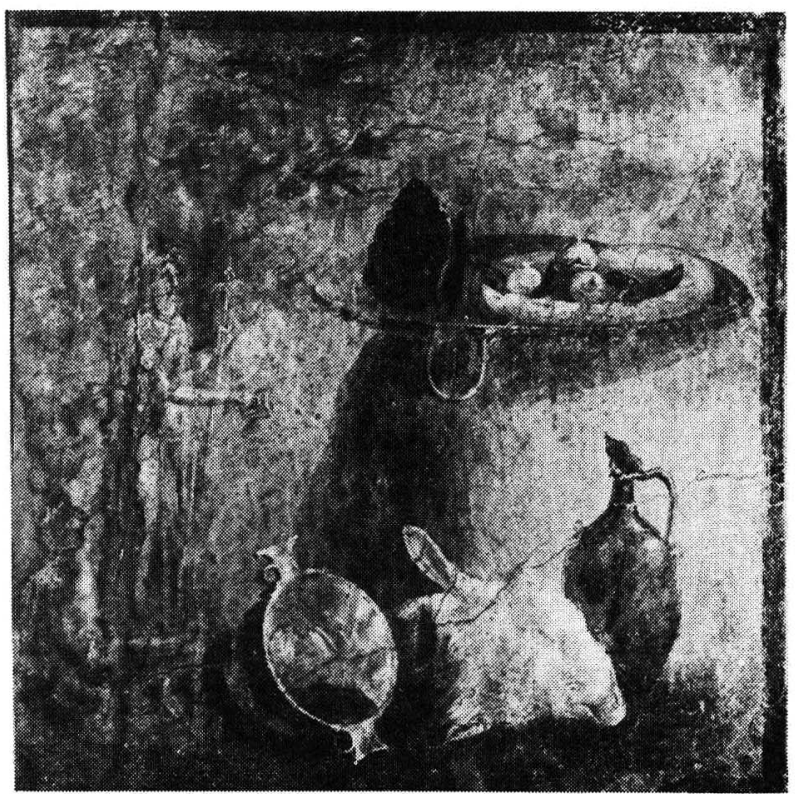

図 4 (出典：Tran Tam Tinh 1988, fig.136.) 


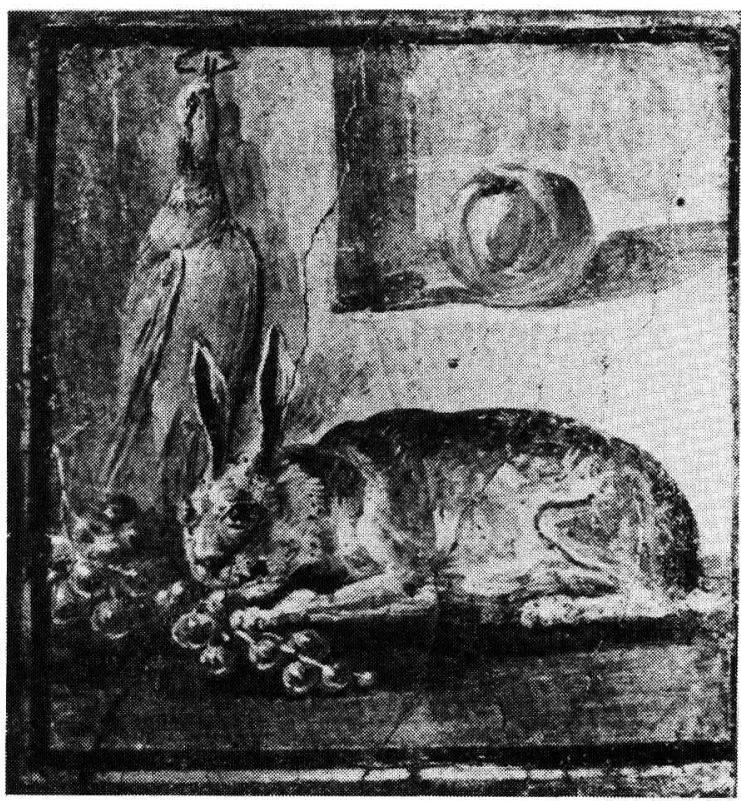

図 5 (出典：Tran Tam Tinh 1988, fig.128.)

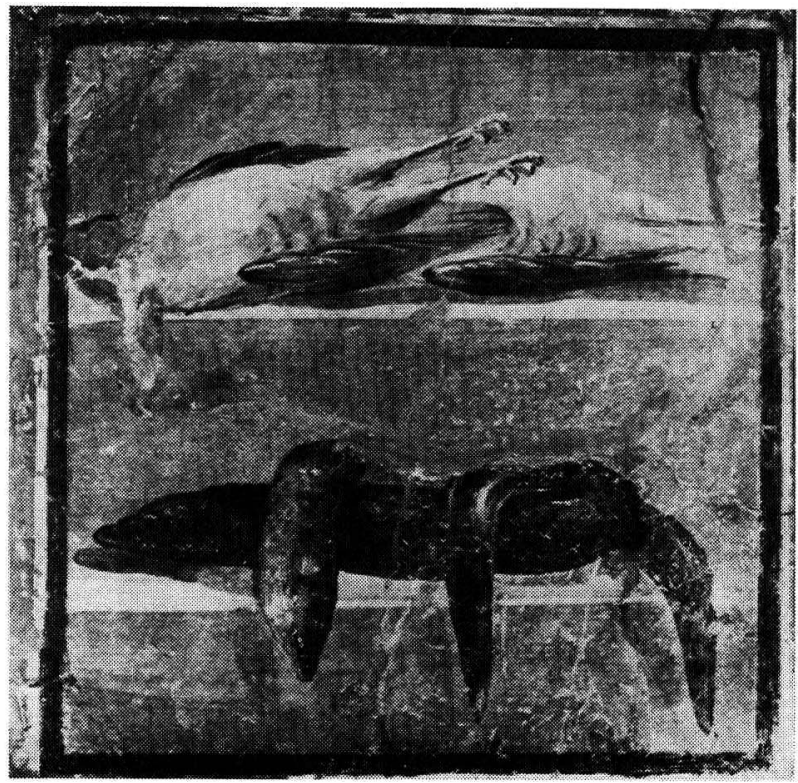

図 6 (出典：Tran Tam Tinh 1988, fig.131.) 


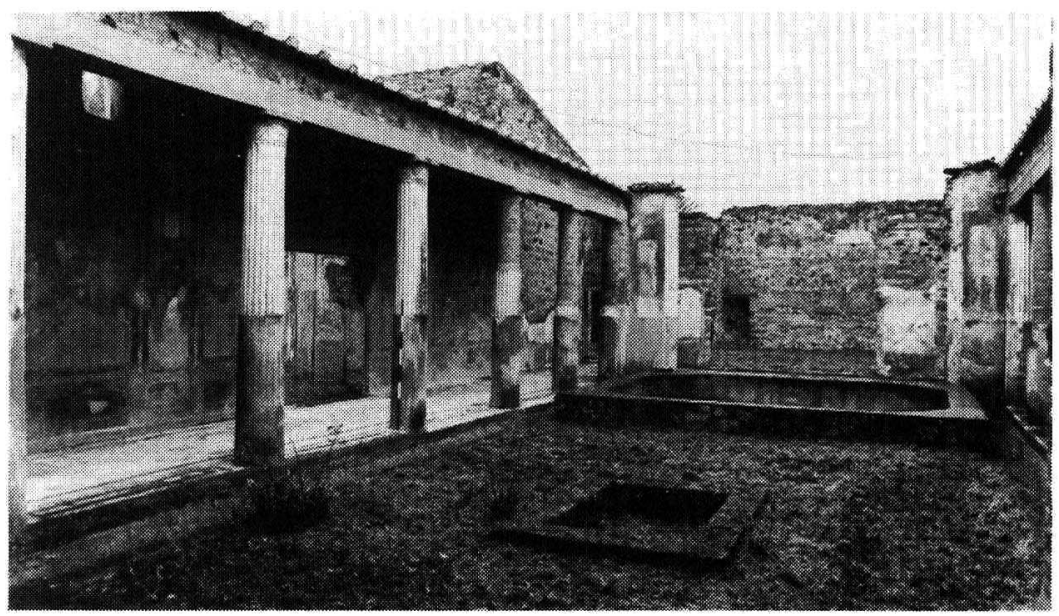

図 7 (出典 : $P P M$ vol.IV, fig.186 a p.956)

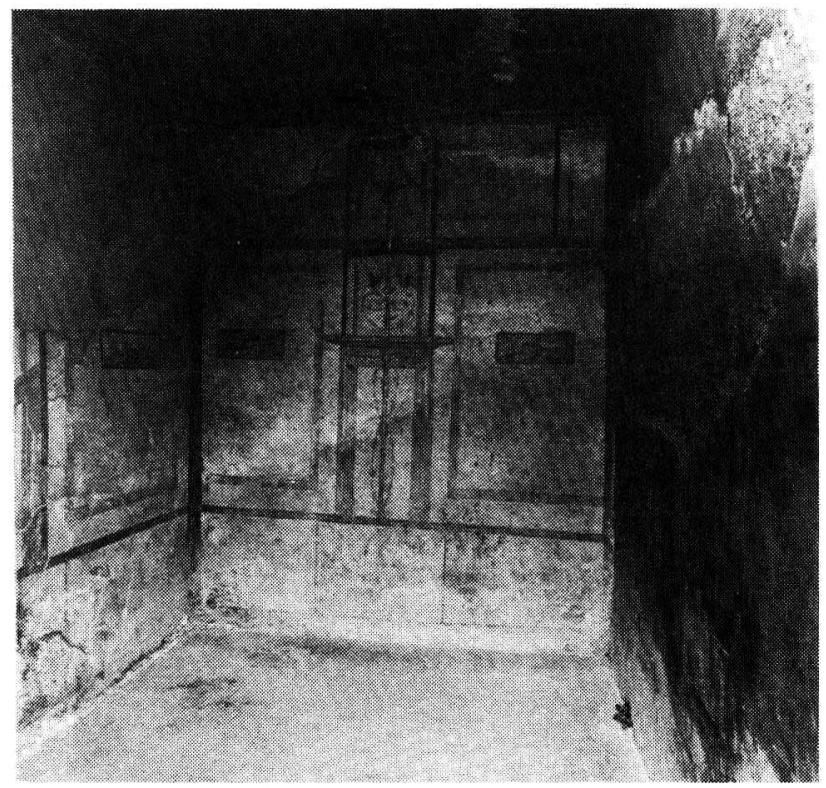

図 8 (出典: $P P M$ vol.I, fig.60b a p.651.) 


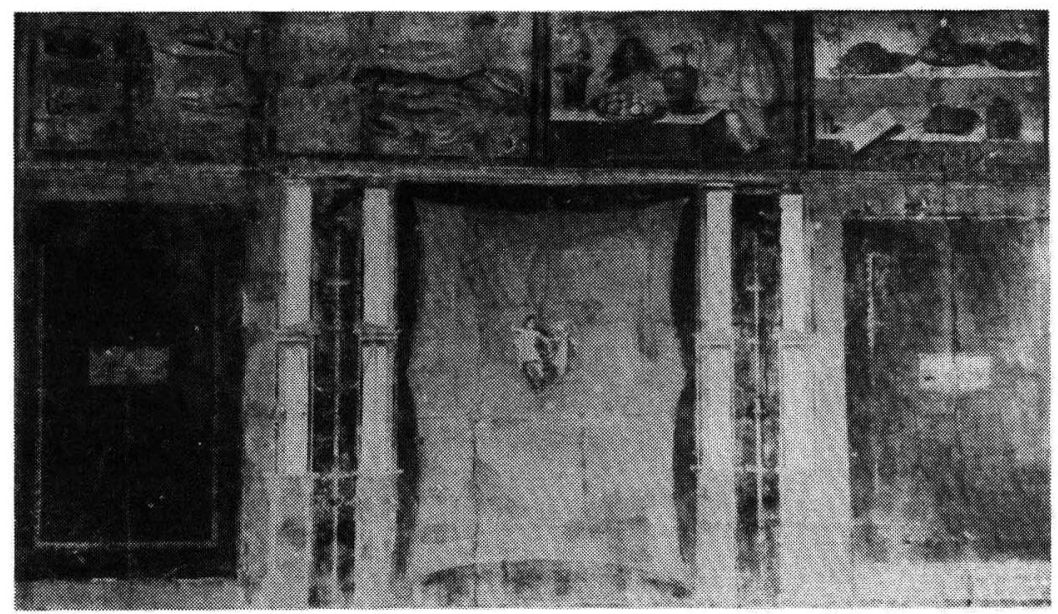

図 9 (出典: $P P M$ vol.III, fig. 177 a p.289.)

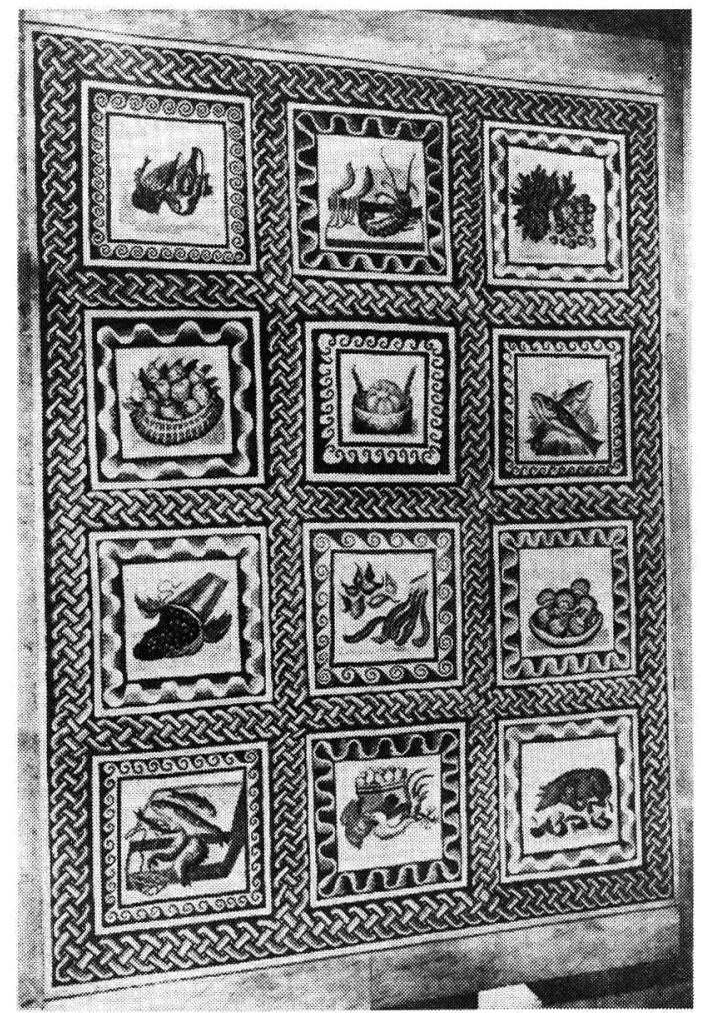

図10（出典：Croisille 1965, fig.194.) 